\title{
ON TEACHING A SECOND SLAVIC LANGUAGE: THE PROBLEM OF SERBO-CROATIAN
}

\author{
Benjamin A. Stolz \\ University of Michigan
}

SERBO-CROATIAN, like other minor Slavic languages such as Polish, Czech, and Bulgarian, is completely secondary to Russian in the few departments where it is offered. Certainly fewer students are now enrolled in Serbo-Croatian than were enrolled in Russian in, say, 1950. Until very recently no more than a dozen of our universities--principally those with well-developed graduate departments granting the Ph.D. in Slavic languages and literatures-have offered courses in Serbo-Croatian on a regular basis. Most universities cannot afford a trained specialist fully committed to such a minor field, and so the teacher of Serbo-Croatian usually also finds himself teaching courses in intermediate Russian, or perhaps Slavic linguistics or literatures. At best, he may find himself cast in the role of the area specialist--the "South Slavic man" who gives courses in everything related to the South Slavic area from Old Church Slavic and a history of the South Slavic languages through surveys of South Slavic folklore and literature as well as the modern literary languages. Depending upon the departmental budget, native speakers may or may not be available as teaching assistants; but because of the perpetual low enrollment in Serbo-Croatian language courses, departmental chairmen are understandably reluctant to employ a native informant in addition to a trained language teacher.

Not only are class enrollments small (at the University of Michigan the enrollment in my beginning SC course has risen from 3 to 9 since fall 1964) but they are diverse. Limited enrollment can be nearly as great a handicap as over-enrollment, for it places a heavier burden on the student and reduces competition, both of which factors lower motivation and interfere with the learning process. Diversity of student backgrounds, however, can be an even more serious problem, for it hampers course planning: a pace and emphasis that will bore some students will baffle and frighten others. Let me give an example. In my first-year Serbo-Croatian course in the fall of 1966 there were nine students and one auditor. Of the nine, four were graduate students from the Slavic Department, three were second-generation Yugoslavs with varying degrees of ignorance of their mother tongue, one was a doctoral candidate in 
economics now doing research in Belgrade, and one was a culturally curious freshman whose grandparents had come from Croatia.

How can one successfully design a course to cater to a group with such unequal levels of sophistication and preparation? The answer, I am afraid, is that it is practically impossible. Graduate students in Slavic all have several years of Russian, sometimes a year or two of Polish, and usually Old Church Slavic before they enroll in Serbo-Croatian. They are able to grasp points of phonology and morphology and to absorb vocabulary with an ease that leaves their classmates gaping in amazement and envy-and perhaps hostility. Conversely, when the teacher takes the time, for example, to explain at some length the system of verbal aspects (which SerboCroatian shares, with some major differences, with the other Slavic languages) to the uninitiated, the insiders can usually be caught staring out the window or checking their watches.

The array of textbooks available for a beginning course in Serbo-Croatian is about as meager as the choice of Russian grammars was, say, in 1950. About five now in print are worth mentioning. I do not intend here to criticize the books at length, but merely to mention a few of their strong and weak points. First, there is Albert Lord's Beginning Serbocroatian.1 Professor Lord is a distinguished collector and scholar in the field of South Slavic epic poetry and a comparative literature specialist. He acknowledges in his preface that the grammar is designed for his own Harvard graduate students who already know one Slavic language. To this purpose it is admirably suited. His thin little text has the advantage of supplying a maximum of grammatical information in 23 lessons and of introducing original, unabridged Serbo-Croatian stories as early as Lesson 18. Its disadvantages for use in mixed undergraduategraduate classes are obvious. The treatment of the phonology and relatively complicated prosodic system is condensed to almost zero. The vocabulary is not large, but aspect pairs are not always supplied. Grammatical explanations are terse. Syntax is almost totally ignored. The exercises for reading and writing are rather short and do not lend themselves readily to stimulating class discussions.

Second, Thomas F. Magner's Introduction to the Serbo-Croatian Language (College Station, 1962) must be mentioned. ${ }^{2}$ The textbook is designed to satisfy the needs both of Americans of Serbian or Croatian descent and college students who have had one other Slavic language, usually Russian. The fact that the grammar is relegated to the back of the book makes the work somewhat unwieldy for

1Reviewed by Vera Javarek, Slavonic and East European Revieu, 37 (1959), 510-511.
2Reviewed by Michael Samilov, Slailic and East European Journal, VII, 2 (1963), 216-217. 
beginning students. Moreover, the grammar and vocabulary in the early lessons are insufficiently graded for immediate classroom use with a mixed group. By lesson two, expressions containing the conditional mood are already introduced, and lesson three offers, for example, such marginal vocabulary as the words for "sleet," "drizzle," "rainbow," "blizzard," and "breeze" in addition to the basic lexicon of weather talk. But the book has solid advantages. The discussion of the sound system and orthography is excellent. Magner provides reading texts which are adaptable to dialog use, good written exercises, and a wealth of historical and cultural information both in and out of the exercises. Finally, there is a reader containing fourteen selections of increasing difficulty, the last three being original Serbo-Croatian stories.

A third grammar was published in 1963: Vera Javarek and Miroslava Sudjit's Teach Yourself Serbo-Croat. ${ }^{3}$ The book is equal to the best efforts in this outstanding series (I am thinking here, for instance, of Teach Yourself Polish and Teach Yourself Turkish, both of which have been used as introductory texts at one of our best universities). In fact, if I were asked to recommend a single SerboCroatian grammar to a non-specialist simply interested in gaining a practical knowledge of the language in the shortest possible time, I would probably cite this little book. The principal faults I find with it are the following: (1) The treatment of the phonology and writing system is sketchy and diffuse. (2) The prosodic notation is simplified to mere positional stress, and even this is not given in the glossary. (3) The cyrillic alphabet is almost completely ignored (probably owing to printing costs). The presence of a key to the exercises bound into the book can be viewed as either an advantage or disadvantage. In any case, it means that additional exercises must always be assigned by the teacher.

The most recent Serbo-Croatian grammar to appear in English is by another British scholar, Monica Partridge: Serbo-Croatian Practical Grammar and Reader 4 (printed in Yugoslavia, 1964, distributed abroad by McGraw-Hill). While Partridge's grammar is perhaps the most ambitious and detailed effort now in print, it has shortcomings in both its organization and presentation of material. The book threatens to drown students in a sea of unclear, atomistic statements, detailed footnotes and parenthetic remarks. The reading exercises are not graded carefully, with the result that various grammatical categories are introduced (and defined in footnotes), and are systematically treated only much later on. Although the

\footnotetext{
338-339.

3Reviewed by Thomas F. Magner, Slavic and East European Journal, VIII, 3 (1964),

${ }^{4}$ See my review, slavic and East European Journal, XI, 1 (1967), 110-112.
} 
grammar is called descriptive, a good measure of unnecessary historical linguistics, some of it misleading or even incorrect, is smuggled in. Most lessons contain a number of sentences for memorization, but unfortunately these seem to have no coherence of their own. For instance, lesson 14 presents the student with 46 totally unrelated sentences (one imagines that they were plucked at random from various sources) as (13) Ušao je odmah u hotel. 'He immediately entered the hotel.' (14) Hram je pretvoren u krstionicu. 'The temple was turned into a baptistry.' and (15) Idemo na drugu stranu ulice. 'Let's go to the other side of the street.' Obviously, there is not much hope for making a dialog of such material. In my view, this grammar would serve better as a second-year review manual and reader.

Another text, Serbo-Croatian Basic Course, I, by Carleton Hodge and Janko Jankovic (Foreign Service Institute, Washington, D.C., 1965), is designed for intensive audio-lingual training and is therefore unsuited for the typical university program. It could be used effectively, however, at a summer institute.

The situation with readers is not much better. Two are presently available.

The first, Vera Javarek, Serbo-Croatian Prose and Verse (London, 1958) offers both Serbian and Croatian selections, but the emphasis is on works of the nineteenth century and there is no glossary. Complete prosodic notation (employing the traditional fouraccent system plus a mark for length) is supplied for two stories; otherwise only positional stress is given.

Ante Kadic's Croatian Reader (The Hague, 1960) is limited to Croatian literature and its glossary is so full of lacunae as to be practically useless-the most difficult vocabulary seems to have been systematically omitted. Accentuation is ignored in the reading material.

The flaws in these two readers are only intensified by the absence of a reliable Serbo-Croatian - English dictionary. At present the student must depend upon dictionaries compiled for Yugoslavs who want to learn English, which naturally enough lack the information a foreigner needs about Serbo-Croatian morphology and accentuation. The only available desk dictionaries supplying details of the sort we are accustomed to in our lexicographical tradition are Serbo-Croatian - Russian and Serbo-Croatian - French works, both of which are useful but unwieldy even for graduate students.

The above are all extrinsic factors and as such are possible to remedy. But there are intrinsic factors peculiar to Serbo-Croatian among the Slavic languages which further complicate the teaching of the language. 
First, as is well known, there are two accepted variants of the literary standard, based on the štokavian dialect: Serbian, centered in Belgrade, and Croatian, centered in Zagreb. The Serbs use the cyrillic alphabet ( cirilica) and the Croats, the roman alphabet (latinica). The two literary variants are close enough to be considered one language, but there are a number of minor differences in morphology, syntax, and lexicon, as well as the underlying phonological dichotomy based on the reflex of the Proto-Slavic vowel jat' $(\check{e})$. The easiest way to state the situation at present is to say that all Croats use the jekavian literary variant where $\check{e} \rightarrow j e, i j e, i, e$, depending upon length and environment, and that most Serbs use the ekavian ( $\check{e} \rightarrow e$ with minor lexical exceptions). Other Yugoslavs from Bosnia-Hercegovina and Montenegro normally use the reflex of their native speech-if it is sto-jekavian (although cyrillic is the official alphabet of Montenegro). Despite the Novi Sad agreement of 1954 and the publication of a joint orthography and terminology in 1960, the struggle between proponents of the two schools has reached major proportions in the last couple of years, culminating in the expulsion of a number of outspoken polemicists from the League of Communists. 5 The Croats, especially, have accused the more numerous Serbs of attempting to push back the jekavian dialect and stamp out Croatian lexical variants.

In any event, what is important for American students is that the two variants of standard Serbo-Croatian still exist, and one or the other or both must be mastered. Although the differences are perhaps no more extensive than those that exist between the variants of the European languages spoken both in Europe and the Western Hemisphere, the fact that they occur in the very young literary language of a single small Balkan country of 18 million people (alongside two other literary tongues, Slovenian and Macedonian) is particularly ironic and confusing for the student even when it comes to such elementary tasks as handling a dictionary.

There is a second intrinsic feature which, if conscientiously taught, can make Serbo-Croatian one of the more difficult Slavic languages to master. This is the so-called neoštokavian prosodic system with its tonal accent (combining length and pitch). ${ }^{6}$ But since educated urban Yugoslavs themselves are far from the prescribed norm in their control of the prosodic system, this feature assumes less importance than one might suppose. Practically, it is only slightly more difficult to teach Serbo-Croatian accentuation than

${ }^{5}$ The author intends to discuss this controversy elsewhere. For statements by leading Croatian scholars, see Jezik. XIII, 5 (1965-1966), 129-132, 150-154.

Gee now Ilse Lehiste and Pavle Ivic, Accent in Serbocroatian: An Experimental Study ("Michigan Slavic Materials," 4, Ann Arbor, 1963). 
Russian. In both instances, extensive drill in the language laboratory and with native informants is the surest method.

These are the special problems of Serbo-Croatian. Allow me to sketch a program designed to surmount them and to provide a reasonably sound knowledge of spoken and written Serbo-Croatian in a two-year course sequence meeting four hours a week.

The two years at our disposal are too short to be spent exclusively in audio-lingual drill, and the materials available do not lend themselves to such an approach. Therefore, in teaching a second Slavic language such as Serbo-Croatian, I am in favor of what has been dubbed the eclectic method-the one, in fact, that most good language teachers have used instinctively for years. Here is how I recommend organizing the two-year course, based on classroom experience.

Prerequisite: Require Russian or the permission of the instructor.

Principle: Teach both alphabets for active use but demand that only one of the literary variants be learned actively; in most instances the ekavian variant will be simpler.

\section{Course Plan:}

1. First semester, first year

a) Cover as much of the grammar as the class mix will allow, using primarily a condensed handbook such as Lord's Beginning Serbocroatian and supplementing by reference to Magner's grammar.

b) Require attendance at the language laboratory, where students hear and repeat the reading exercises and vocabulary from Lord's grammar.

c) Give additional pattern drills and carry on conversations in class; toward the end of the semester, assign dialogs for class presentation from Magner's grammar (all of which are taped for easy and correct learning).

2. Second semester, first year

a) Finish Lord's grammar, the last lessons of which are a reader, and begin additional reading and translating in Magner's textbook-which provides readings on various cultural and historical topics as well as belles-lettres.

b) Continue dialogs from Magner.

c) Begin Kadic's Croatian Reader. 
3. First semester, second year

a) Finish Kadic and begin Javarek, Serbo-Croatian Prose and Verse (a dictionary is now required).

b) Supply additional grammar, especially syntax.

c) Practice composition and conversation (based on reading).

4. Second semester, second year

a) Finish Javarek and introduce short stories bÿ Andric and Krleža as well as examples of current expository prose.

b) Continue supplementary grammar.

c) Practice composition and conversation.

This is an outline of my approach. I am convinced that the audio-lingual method without extensive reading and writing is a waste of time as a means of teaching a second Slavic language when only four regular semesters are available.

If the results are uneven and discouraging, we should keep heart. Usually even the most diligent students in such courses are primarily interested in Russian-and in fact they may be fearful of losing their Radio Moscow accents by contamination with a lesser Slavic dialect. But the rewards are unusually high: the Yugoslavs (and other small Slavic peoples) are continually amazed to meet Americans who have taken the trouble to learn their language with some degree of proficiency. A firm grasp of a second Slavic language will increasingly become not just a requirement listed in graduate catalogs, but a real necessity as Slavic studies develop in the United States. Those of our students who in fact want to learn a second Slavic language such as Serbo-Croatian can go a long way toward doing so, I believe, in a two-year program of the sort I have outlined.

Obviously, a student who wants to attain real mastery of SerboCroatian cannot terminate his study after a four-semester sequence. Two kinds of possibilities for continued study exist. Many wellestablished graduate departments now offer advanced courses in Serbo-Croatian literature and folklore as well as linguistics. It is especially encouraging to note the number of exchange and fellowship programs under which qualified students can spend a summer, a semester, or a full academic year in Yugoslavia. By pursuing either or both of these opportunities, an interested student can consolidate and expand his knowledge of the language. The results he obtains will rest heavily on the foundation built in the first two years of study. 